ストライエーション形状から荷重を推定する方法について†

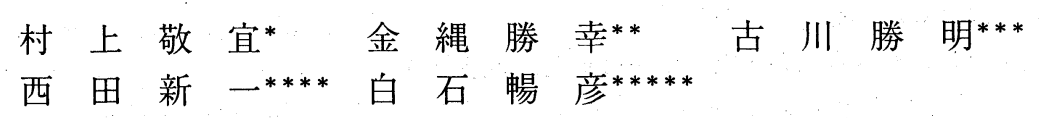

\title{
A Method for Predicting Service Load from the Width and Height of Striation
}

by

\author{
Yukitaka Murakami*, Katsuyuki Kanenawa**, Katsuaki Furukawa*** \\ Shinichi NiSHIDA**** and Nobuhiko SHIRAISHI ${ }^{* * * * *}$
}

For the prediction of service load from fatigue fracture surface, not only the measurement of striation spacing(s) but also the information on stress ratio are necessary.

In the previous paper, the authors found that there was one to one correspondence between the ratio of striation height $H$ to $s(H / s)$ and the stress ratio $R$ for 2017-T4 aluminum alloy. Since $s$ ranges approximately from 0.1 to $2 \mu \mathrm{m}$ and $H$ is smaller than $s$, the prediction of accurate $R$ value requires the accurate measurement of $H$ and $s$. For this purpose the procedure composed of cutting, polishing by emery paper and buff polishing was utilized previously. In this paper, an improved method using Microtome to reveal sharp striation sections is proposed and the improvement of measurement accuracy is shown.

In addition to 2017-T4 aluminum alloy, type 304 stainless steel was investigated in order to study the effect of mechanical properties on the relationship between $H / s$ and $R$. The experimenal results gave almost the same relationship for type 304 stainless steel and 2017-T4 aluminum alloy. This result implies that the $H / s-R$ relationship is independent of material properties, suggesting that one master curve of $H / S-R$ and striation spacing $s$ give a crucial information about the service load at the occurrence of fatigue fracture accidents.

Key words : Fatigue, Striation, Striation width, Striation height, Service loading, Crack propagation, Stress intensity factor range, Stress ratio

\section{1 緒 訔}

機械構造物の破壊事故は, その原因の $80 \%$ 以上が 疲労破壊によるといわれている。このため, 損傷破面 を解析し，その損傷時に加わった荷重を推定すること は事故の再発防止からも意義がある．特に破面上に残 されたストライエーションは,この疲労破壊の原因に 関する重要な情報源である.

ストライエーションのほとんどは応力サイクルとよ く対応しており，き裂伝ぱ速度とストライエーション 間隔はよく一致することが知られている.さらに，き 裂伝ぱ速度 $d a / d n$ およびストライエーション間隔 $s$ と応力拡大係数幅 $\Delta K\left(=K_{\max }-K_{\min }\right)$ との関係は Paris 則を満足するので, 破面に残されたストライエ ーション間隔から実働荷重を推定しようという試みが なされてきた。しかし, 実際には応力比 $R$ が異なれ
ば $d a / d n$ あるいは $s$ と $\Delta K$ との関係は 1 対 1 には 決められなくなる。 また, 有効応力拡大係数幅 $\Delta K_{\text {eff }}$ $\left(=K_{\max }-K_{\mathrm{op}}\right)$ を用いれば $d a / d n$ および $s$ の関係は $R$ の幅にかかわらずほぼ 1 本の帯状に整理できると いわれている. ᄂかし，このとき開口比 $U\left(=\Delta K_{\mathrm{eff}}\right.$ $/ \Delta K)$ が測定できなければ $\Delta K_{\text {eff }}$ は求まらない。実際 の破壊事故の際には, 開口比 $U$ を測定することは, ほとんど不可能であるので, 破面からどのようにして $U$ を推定するかが問題となる. 細かい議論を別にす れば，開口比 $U$ は $R$ によってほぼ決まるとされ，開 口比 $U$ を推定するには, 破面から $R$ を推定すること が重要である. ストライエーションの形態と $R$ と) 関係については定性的な考察がなされているが，著者 らの調査した限り定量化に成功した例はないようであ る. 前報で, 著者らは 2017- $\mathrm{T} 4 \mathrm{Al}$ 合金を用い, $R$ の

$\dagger \quad$ 原稿受理 平成 2 年 8 月22日 Received Aug. 22, 1990

* 正 会 員 九州大学工学部 福岡市東区箱崎, Faculty of Engineering, Kyushu University, Hakozaki, Higashi-ku, Fukuoka

** 九州大学大学院 福岡市東区箱崎, Graduate Student, Kyushu University, Hakozaki, Higashi-ku, Fukuoka

*** 正 会 員 九州管区警察局 福岡市博多区東公園, Kyushu Regional Police Bureau, Higashi-koen, Hakata-ku, Fukuoka

$* * * *$ 正会員 新日本製鉄(株) 北九州市八幡東区, Nippon Steel Corporation, Yawatahigashi-ku, Kitakyusyu

$* * * * *$ 消防庁 東京都千代田区霞が関, Fire Defense Board, Kasumigaseki, Chiyoda-ku, Tokyo 
違いが主としてストライエーションの形状の違い, 特 にその高さ $H$ と幅 $s$ の比の違いにあらわれることを 見いだした。 その結果ストライエーションの高さ $H$ と幅 $s$ の比 $(H / S)$ と応力比 $R$ との間にはほほ 1 対 1 の対応があることを明らかにした. 実際には， $s$ は $0.1 \sim 2 \mu \mathrm{m}$ 程度, $H$ はさらに小さいので, 破面の $H$ / $s$ から $R$ を決定するためには， $H$ と $s$ を高精度で 測定する方法を確立することが重要である. 前報では 1 つの方法を提案したが, 本報ではその方法と, さら に改良した方法とそれによる結果を報告する，さらに， $H / s$ と $R$ の 1 対 1 の関係が材料によってどのように 変化するかを知るために, SUS304についても同様 な実験を行った:

\section{2 使用材料, 試験片の形状および実験方法}

\section{$2 \cdot 1$ 使用材料および試験片形状}

使用材料は 2017-T4Al 合金および SUS 304 である. Table I に機械的性質, Table II に化学的成分を示す. Fig. 1 にCT 試験片, Fig. 2 に中央切欠き試験片の形 状を示す. 疲労試験は油圧サーボ式疲労試験機を用い, $R$ と荷重 $P$ の種々の組み合わせについて, き裂伝ぱ 試験を行った。このようにして形成された疲労破面を 走査型電子顕微鏡 (SEM) によって観察し, ストラ

Table I. Mechanical properties.

\begin{tabular}{l|c|c|c}
\hline & $\sigma_{0.2}(\mathrm{MPa})$ & $\sigma_{B}(\mathrm{MPa})$ & $\psi(\%)$ \\
\hline A2017-T4 & 270 & 435 & 23.8 \\
\hline SUS304 & 371 & 650 & 72.0 \\
\hline $\begin{array}{l}\sigma_{0.2}: 0.2 \% \text { proof stress. } \\
\sigma_{B}: \text { Ultimate tensile stress. } \\
\psi: \text { Reduction of area. }\end{array}$
\end{tabular}

Table II. Chemical composition. A2017-T4

\begin{tabular}{c|c|c|c}
\hline $\mathrm{Cu}$ & $\mathrm{Mg}$ & $\mathrm{Mn}$ & $\mathrm{Si}$ \\
\hline 3.7 & 0.6 & 0.4 & 0.4 \\
\hline \multicolumn{4}{c}{ SUS304 }
\end{tabular}

\begin{tabular}{c|c|c|c|c|c|c|c|c}
\hline $\mathrm{C}$ & $\mathrm{Si}$ & $\mathrm{Mn}$ & $\mathrm{P}$ & $\mathrm{S}$ & $\mathrm{Ni}$ & $\mathrm{Cr}$ & $\mathrm{Mo}$ & $\mathrm{Al}$ \\
\hline 0.06 & 0.47 & 0.89 & 0.028 & 0.005 & 8.59 & 18.28 & 0.118 & 0.022 \\
\hline
\end{tabular}

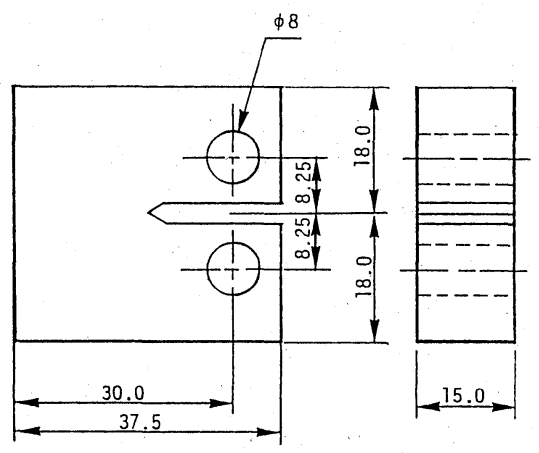

Fig. 1. CT specimen.


Fig. 2. Center notched specimen.

イエーション間隔 $s$ および形状 $H / s$ を測定した.

\section{$2 \cdot 2$ ストライエーション形状の測定法}

観察されるストライエーションはその幅が $0.1 \sim 2$ $\mu \mathrm{m}$ 程度, 高さはさらに小さな值をとるため, 測定は きわめて困難であるが，この困難を解決することが問 題解決の鍵となる.

そこで, 著者らはストライエーション断面形状の高 精度測定方法として前報で 1 つの方法を提案した.こ の方法はストライエーションを斜めにある角度で切断 することによって, 特にその高さを誇張し, 高さの測 定を容易にしょうというものである。このときストラ イエーションの切断方法の良否が断面形状の測定精度 に影響を与える．前報の方法でもストライエーション 形状測定は可能であったが, 次の三つの問題点があっ た.

(1) エメリペーパー，ダイヤモンドコンパウンド, およびバフによる研磨の過程において，破面を保護す る目的に用いた樹脂と研磨面との境界部分で金属部分 にだれを生じやすく，ストライエーション断面が鮮明 さを欠く傾向がある.

（2）試験片の樹脂への埋め込みから断面作成までに 長い時間がかかる.これは旋削, 研磨など行うべき処 理の数が多いためである.

(3) 一回の断面作成によってストライエーション形 状を決定していたが，この方法では得られる情報は多 いとはいえない. 信頼できる多くの情報を得るために は, 一つの試験片について, 複数回の断面作成が望ま しい. しかし, 前報の方法では, 試験片の形状の問題 から複数回の断面作成が困難であった.

これらの問題点を解決するために, 本研究では, ミ クロトームを使用して断面を削ることにより改良を 四った。

なお, SUS 304 は硬度が高く通常の刃（高炭素鋼） ではミクロトームの適用が困難であったので, 本研究 では，まず前報の方法でストライエーションの形状を 測定した. しかし, 測定結果は十分満足いくものでは なかったので, 次に，炭素鋼の刃の代わりにタングス テンカーバイト鋼の刃を用いて，ミクロトームを適用 した.

Fig. 3 に改良された方法のフローチャートを示す.

Fig. 4 に示すように, CT 試験片および中央切欠き試 


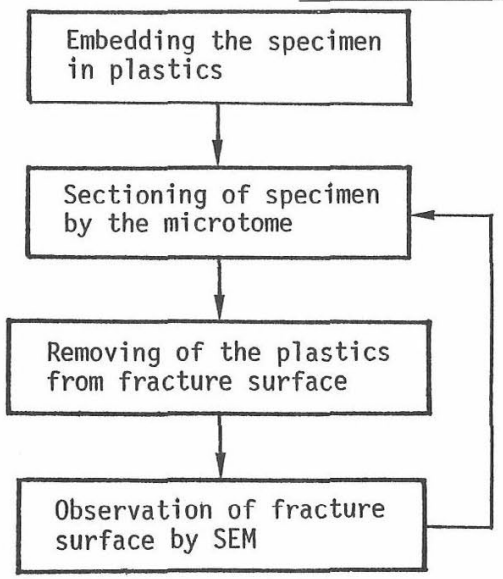

Fig. 3. Flow chart of the improved method.

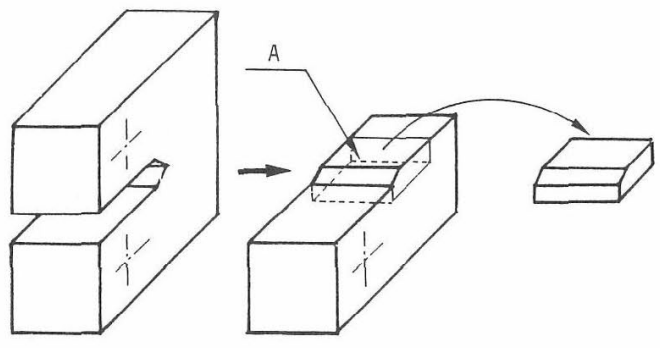

Fig. 4. SEM specimen cut from fatigue specimen.

験片より瘦労破面を持った部分 $\mathrm{A}$ を切りだす。さ にその破面を Fig. 5 のように切断面に対して 20 度〜 45 度傾けて埋め込み試料を作成する。 さらにこの試 料をミクロトームを用いて切削する。

最後に,イオンスパッタにより金蒸着を約 $50 \AA$ ほ どこして観察試料とした。

なお，ミクロトームによる試料制作に際しては, 以 下のような注意が必要である。(1) ミクロトームの刃 が切断開始時から試料の金属面全体に当たると切断不 能となりやすいので，刃に対して $2 ， 3$ 度の角度をも たして試料を取り付ける。(2) 送りが小さすぎると一 回当たりの削る量が少なくなりすぎ切断不能となりや すいので， $0.75 \mu \mathrm{m}$ 程度の送りを用いて切削する。(3) 樹脂に埋め込んだ試料を切削する際，金属面から刃を いれると切断の切属のかえりの発生のためストライエ ーションの断面が見えにくくなるので, 刃が樹脂から 試料に当たるように取り付ける.

このようにして，ミクロトームの採用により，前報 の方法 (切削, ペーパ研磨, バフ研磨) に比べ, 樹脂 と金属部分の境界のだれを減少させ，測定精度をあげ ることに成功した。

\section{3 実験結果および考察}

$3 \cdot 1$ 改良された方法と前報の方法の断面写真の比 較

Fig. 6 および Fig. 7 に，2017-T4Al 合金および



SUS 304 にお改良された方法および，前報の方 法によって切断されたストライエーションの断面写真 を応力比別に示す. 改良された方法による断面写真で はストライエーションの形状が鮮明となり, H/sの 測定精度が向上することが期待できる.

$3 \cdot 2$ 改良後の切断方法による $H / s$ と $R$ の関係

Fig. 8 は 2017-T4Al 合金に扔いて, 前報の切断方 法で求めたストライエーションの高さと幅の比 $\mathrm{H} / \mathrm{s}$ と応力比 $R$ との関係と, 改良後の切断方法を用いて 測定した $H / s$ と応力比 $R$ との関係を比較したもので ある。両者の值の分布に若干のずれが見られるものの 同様の傾向を示している.

Fig. 9 は SUS 304 について同様な結果を示したも のである．2017-T4Al 合金とは異なり，前報の方法 と改良された方法とでは測定結果のばらつきの幅がか なり異なる．このことは，アルミ合金のような柔らか い材料では前報の方法でも改良された方法でもストラ イエーションの切断に大きな差が生じないが，材料の 硬度が増すと前報の方法では研磨の過程で切断面の端 にかなりのだれを生じるため高精度の測定が望めない ことを示している．改良された方法によれば SUS 304 のような材料でも Fig. 9 に示すように測定結果の ばらつきの幅は小さくなることがわかる.

\section{$3 \cdot 3 \mathrm{SUS} 304$ の $\mathrm{H} / \mathrm{s}$ と $\boldsymbol{R}$ の関係}

Fig. 10 はSUS 304 と 2017-T4Al 合金における改 良された方法の $H / s$ と応力比 $R$ との関係を比較した ものである。この図で明らかなように， SUS 304 と 2017-T4Al 合金の $H / s$ と $R$ の関係はばらつきがあ るものの, 有意な差は認められない. 


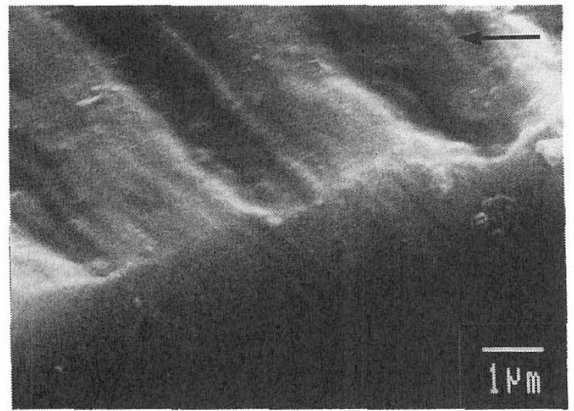

(A)

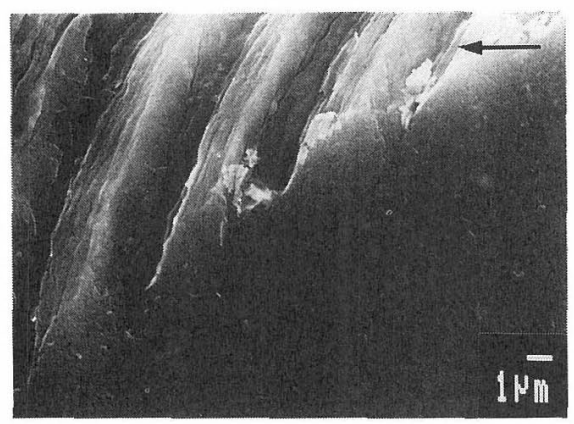

(A)

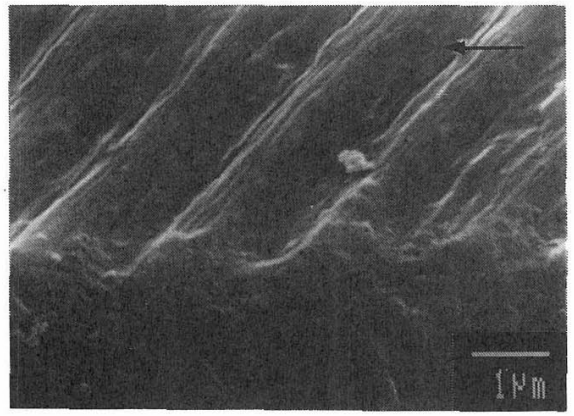

(A)

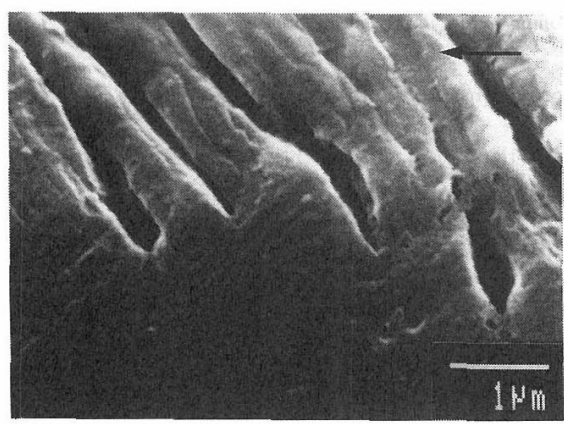

(

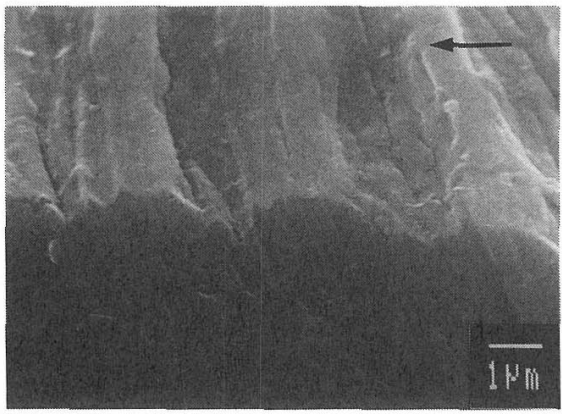

(B)

(a) $R=-1$.

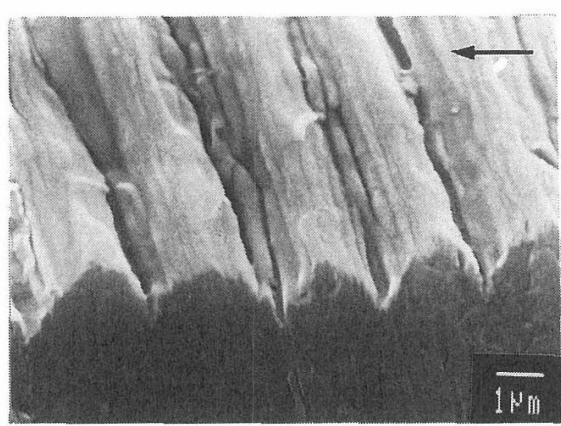

(B)

(b) $R=0.1$.

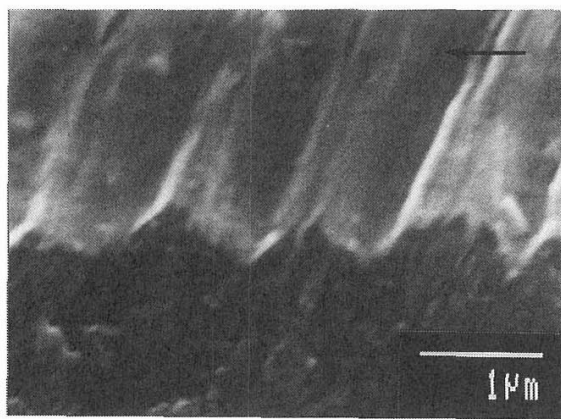

(B)

(c) $R=0.3$.

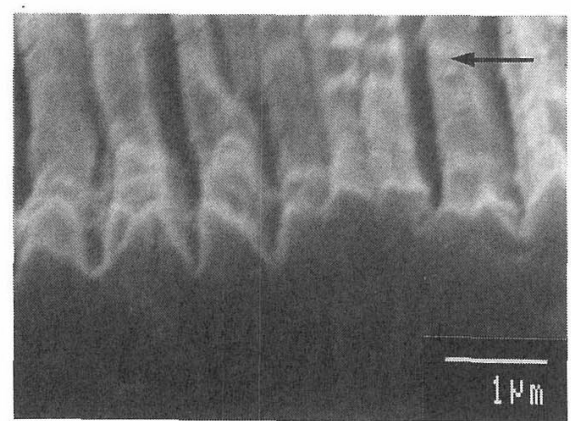

(B)

(d) $R=0.5$.

(A : Sectioning by the previous method, B : Sectioning by the improved method.) ( Direction of crack propagation)

Fig. 6. Sectioning of striations on 2017-T4 Al alloy by the improved method and the previous method. 




(A)

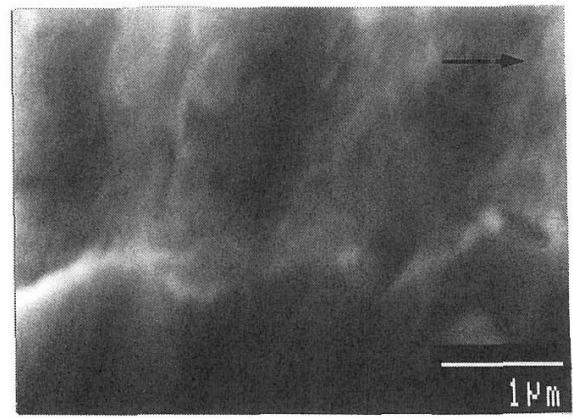

(A)

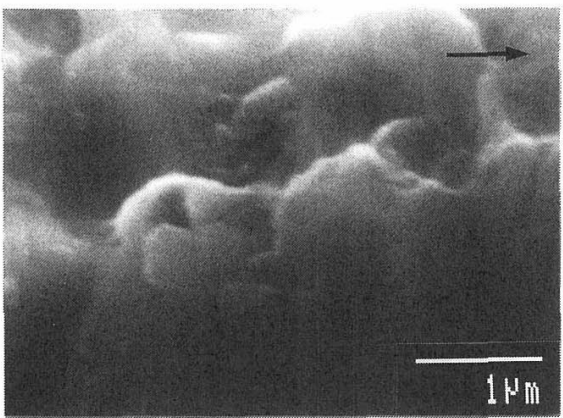

(A)

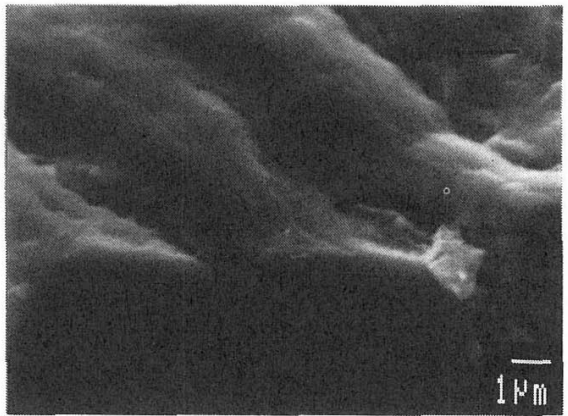

(B)

(a) $R=-1$.

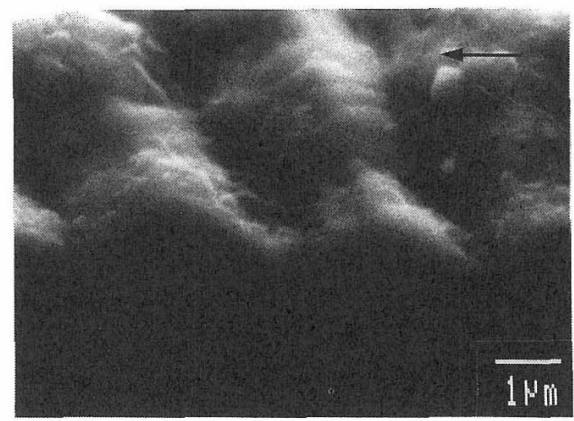

(B)

(b) $R=0$.

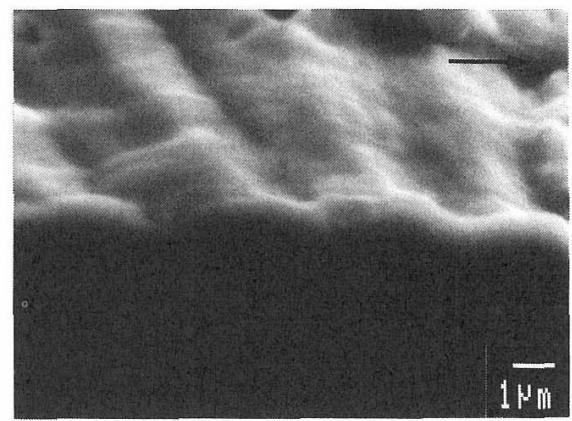

(B)

(c) $R=0.3$

(A : Sectioning by the previous method, B : Sectioning by the improved method.) $(\leftarrow$ : Direction of crack propagation.)

Fig. 7. Sectioning of striations on SUS304 by the improved method and the previous method.

実験結果の数も必ずしも十分ではなく, 材料も 2 種 類の検討結果だけであるから，このことから一般的な 結論を導くことは危険であるが，Fig. 10 の結果は, 材質が変化しても $H / \mathrm{s}$ と $R$ の関係は変わらないこと を予想させるもので，実用的には極めて重要な意味を 持っていると考える.

な㧍，ストライエーションの形成機構をもとにして Fig. 10 の結果を半理論的に導くことも可能かもしれ ないが，著者らはまだそれに成功していない。

$$
4 \text { 結 言 }
$$

疲労破面の状況から実働荷重を推定することは, 破
壞の原因や破壞事故時の状態などを知るうえで実際上 重要な意味をもっている. 本研究では，ストライエー ション形状加実働荷重を推定する一つの方法を提案 した，それはストライエーションの幅がき裂伝ぱ速度 と対応し，ストライエーションの高さと幅の比が応力 比 $R$ と一義的な関係にあることにもとづいたもので ある. ストライエーションの高さは $0.1 \mu \mathrm{m}$ のオーダ であるので, 高さの高精度測定が応力比決定の鍵とな る。前報では, 試料を傾けて切断した後, ペーパ研磨, バフ研磨をほどこす方法を提案したが，本報では新た にミクロトームの採用により測定精度と信頼性の向上 


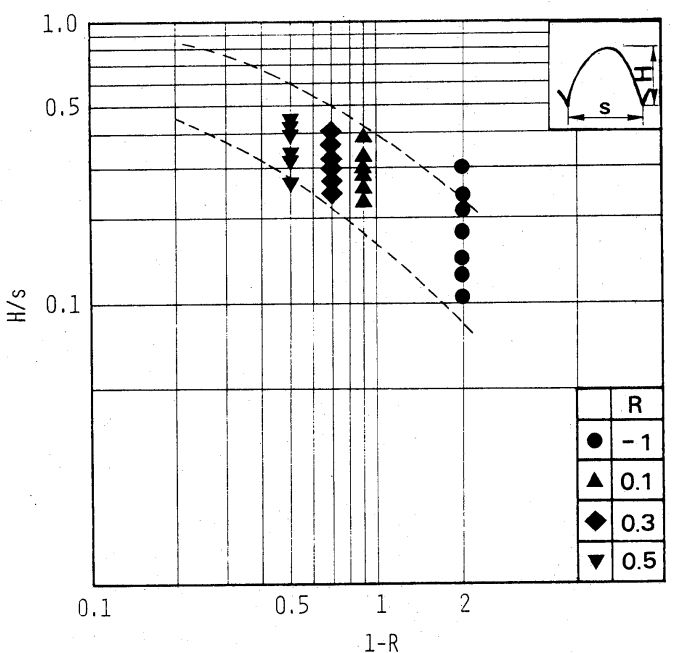

Fig. 8. Relationship on 2017-T4 Al alloy between stress ratio $R$ and $H / s$ (height and width ratio) obtained by the improved method.

Dotted line indicates the scatter band of measurement by the previous method.

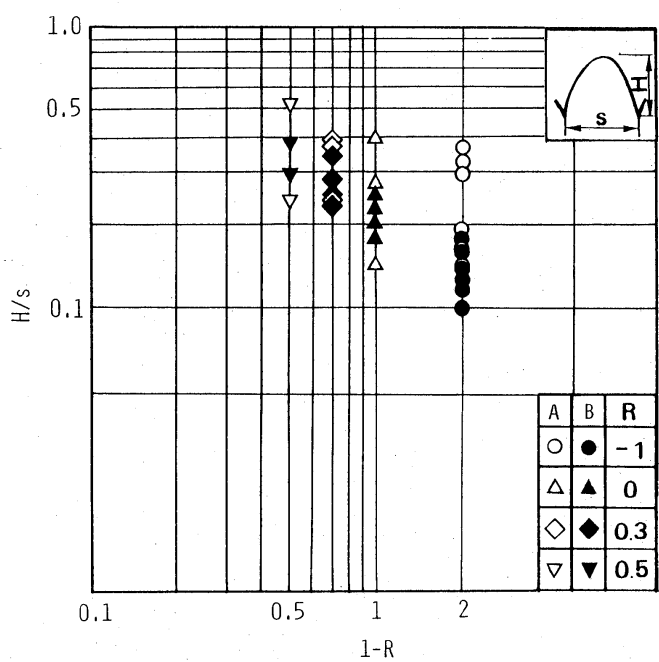

Fig. 9. Relationship on SUS304 between stress ratio $R$ and $H / s$ (height and width ratio) obtained by the previous method (A) and by the improved method (B).

が達成できることを示した。

(1) $\mathrm{Al}$ 合金などのように柔らかい金属にのみでな くSUS 304 に対しても, 改良された断面作成法の適 用が可能である。これによって，ストライエーション の断面の鮮明化，断面作成時間の短縮化および断面の 複数個作成が実現でき, ストライエーションの高さと 幅の比 $H / s$ の高精度測定と信頼性の向上が達成でき た.

(2) SUS 304 の $H / s$ と $R$ の関係は 2017-T4Al 合

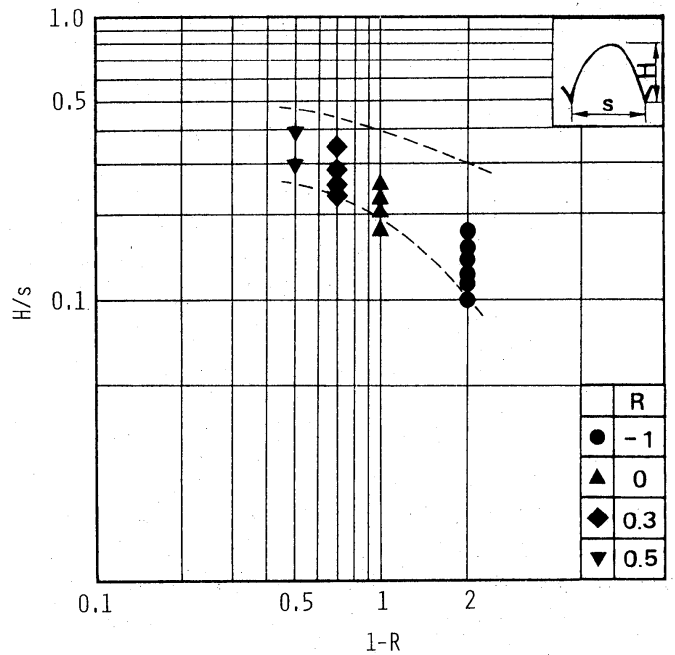

Fig. 10. Relationship on 2017-T4 Al alloy and SUS304 between stress ratio $R$ and $H / s$ (height and width ratio).

Dotted line indicates the scatter band of measurement of 2017-T4 Al alloy obtained by the improved method.

金のそれとほぼ一致した。

このことは，材質が変化しても $H / s$ と $R$ の関係は 変わらないことを予想させるもので, 疲労破面から実 働荷重を推定する際，実用的に重要な意味をもつもの と考える.

(平成 2 年 6 月 22 日 第 7 回フラクトグラフィシンポジウムにて講演)

\section{参 考 文 献}

1 ） 日本機械学会フラクトグラフィ分科会報告, 日本機械学 会誌, 76, 1203 (1973).

2) 小寺沢良一, 材料, 23, 803 (1974).

3 ) A. Madeyski and L. Albertin, ASTM STP645, B. M. Strauss and W. H. Cullen Jr., Eds., 73 (1978).

4 ）橘内良雄，材料，32，355（1983）.

5 ）橘内良雄，材料， 36，431 (1987).

6) J. C. McMillan and R. M. N. Pelloux, ASTM STP415, 505 (1967)

7 ) 小寺沢良一, 材料, 23, 593 (1974).

8 ）小寺沢良一，本上 勉, 材料, 23，730 (1974).

9 ) A. J. Krasowsky and V. A. Stepanenko, Int. J. Fract., 15, 203 (1979).

10) R. W. Herzberg and E. F. Von Euw, Metallurgical Transactions, 4, 887 (1973).

11）北川英夫，小寺沢良一, “フラクトグラフィ”, p. 112 (1977) 培風館

12）城野政弘, 宋 智浩, 三上省二, 大垣雅由, 材料, 33, 468 (1984).

13）村上敬宜, 古川勝明, 白石暢彦, 材料, $\mathbf{3 9}, 1113$ (1990).

14) C. Laird, ASTM STP415, 131 (1967).

15) R. M. N. Pelloux, Engng. Frac. Mech., 1, 697 (1970).

16) C. G. Bowles and D. Broek, Int. J. Fract. Mech., 8, 1, 75 (1972) 